\title{
The founding of the Psychonomic Society
}

\author{
DONALD A. DEWSBURY \\ University of Florida, Gainesville, Florida \\ and \\ ROBERT C. BOLLES \\ University of Washington, Seattle, Washington
}

\begin{abstract}
The Psychonomic Society falls within a long tradition of efforts to create organizations of psychologists as alternatives to the American Psychological Association, which has frequently been perceived as failing to meet the essential needs of some of its constituents. As the result of 1950 s discussions and correspondence centered on the need for more effective communication among psychologists doing scientific research, an Organizing Committee was formed to undertake the task of designing a new scientific society from the ground up. The Psychonomic Society was founded by a group of experimental psychologists meeting in Chicago, Illinois, in December 1959. They fashioned the Psychonomic Society to provide maximal opportunities for communication about science with minimal bureaucratic structure and without frills unrelated to free and open scientific exchange.
\end{abstract}

This story begins at the meetings of the American Association for the Advancement of Science (AAAS) in Washington, D.C. between Christmas and New Year's Day in December 1958. There was at that time among experimental psychologists a general unhappiness with the directions being taken by the American Psychological Association (APA). The feeling was that the APA was moving too strongly in the direction of professional (i.e., practice-related) psychology at the expense of experimental work. A particular concern was the format of the annual convention, which was perceived as being inappropriate for the communication and discussion of experimental results. Too little time was allotted for the presentation of papers in experimental psychology, and it was too difficult at the large meetings to locate colleagues with similar interests. There was even a ban on the use of slides at the convention. One particular discussion during the AAAS meetings occurred in a bar in Washington; it appears to have included Clarence Graham of Columbia University, Clifford T. Morgan of Johns Hopkins, S. S. Stevens of Harvard, and William S. Verplanck of Hunter College. Surely there have been many such discussions at

\footnotetext{
Robert C. Bolles, the first historian of the Psychonomic Society, died on April 8, 1994, after having written a draft of this article. The article was completed by Donald A. Dewsbury, his successor. The order of authorship is that suggested by the editor and reviewers. This project would have been impossible had not William S. Verplanck not only played a critical role in the founding of the Psychonomic Society, but also carefully preserved many of the documents generated in the process. We thank Ludy T. Benjamin, Jr., William K. Estes, Wendell R. Garner, Lloyd G. Humphreys, John A. Popplestone, Endel Tulving, William S. Verplanck, and anonymous reviewers for comments on various drafts of the article. We thank David E. Irwin for information regarding the GUV. Please address correspondence to D. A. Dewsbury, Department of Psychology, University of Florida, Gainesville, FL 32611 (dewsbury@webb.psych.ufl.edu).
}

many meetings. This one, however, can be singled out as the occasion on which a new society was first conceived. Two years later the Psychonomic Society had been organized and incorporated, held its first meeting, and published its first newsletter. This is the story of the events of that 2-year period of gestation (see also Garner, 1976). It is the first in a series of articles dealing with the history of the Psychonomic Society. Future articles will deal with such topics as the publications program, annual scientific meetings, and governance of the society.

\section{THE AMERICAN PSYCHOLOGICAL ASSOCIATION: SECESSIONS AND SPLINTER GROUPS}

Some background concerning a variety of similar organizations of psychologists is necessary if the Psychonomic Society is to be understood in context. The founding of the Psychonomic Society was one in a series of efforts to meet the particular needs of groups of psychologists, especially to provide an adequate forum for the presentation and discussion of psychological research.

The American Psychological Association was founded on July 8, 1892 in the living room of G. Stanley Hall in Worcester, Massachusetts (Dennis \& Boring, 1952; Evans, Sexton, \& Cadwallader, 1992; Fernberger, 1932). It was organized to advance psychology as a science. The APA has survived for more than a century as the primary organization of psychologists in North America. Nevertheless, throughout its history, there have been numerous splinter groups organized either in opposition to or as complements to the APA. Psychology is such a diverse discipline that it is difficult to conceive of any umbrella organization meeting all of the needs of all of its members all of the time. Although it may be somewhat of an oversimplification, it is nonetheless generally true that 
the splits have generally involved conflicts between psychologists engaged in the delivery of services (i.e., practice) and those engaged in basic research. Splinter groups have been formed on both sides.

\section{Dissention From the Practice Side}

On December 28, 1917, a group of psychologists interested in advancing the practice of psychology, led by J. E. W. Wallin and Leta Hollingworth, met and formed the American Association of Clinical Psychologists (AACP) (Hilgard, 1987; Watson, 1953). Much opposition and hostility was generated between the new organization and the APA, but in 1919 it merged with the APA as the Section of Clinical Psychology, the first "section" in the APA. The Association of Consulting Psychologists (ACP) was established in New York in 1921.

By 1921, the admission standards for APA membership had evolved to include both the $\mathrm{PhD}$ and acceptable published research. In 1925, however, the category of Associate in APA was created to encompass psychologists who were doing applied work and had little opportunity to publish the results of their efforts. This led to increased growth of the organization and pressures from clinical, consulting, educational, and industrial psychologists within it to get the APA to meet their needs. These efforts eventually led to the formation of the American Association for Applied Psychology (AAAP), a group independent of the APA, in Minneapolis in 1937. The 600 or so members of the AAAP were generally also members of the APA, which had about 4,000 members at this time (Hilgard, 1987). The AAAP was the most significant of the practice-oriented organizations, however; it led a reorganization of the entire APA.

World War II led to an increased professionalization of psychology and to cooperation among the various organizations of psychologists, which by then included the AAAP, the APA, the Psychometric Society, Section I of the AAAS, the Society of Experimental Psychologists, and the Society for the Psychological Study of Social Issues, among others. An Intersociety Constitutional Convention of Psychologists was held May 29-31, 1943 at the Pennsylvania Hotel in New York City. The result was the restoration of the APA as the umbrella organization for psychology, with a revised set of bylaws and a divisional structure. A change of great significance to the founders of the Psychonomic Society was that the purpose of the APA became the advancement of the science and practice of psychology. According to the new bylaws, one could become a Fellow (full member) of the APA with a PhD, prior membership as an Associate, and either published research beyond the doctorate or 4 years acceptable professional experience; the latter provision mollified the practice-oriented psychologists but further alienated the basic researchers. The new structure became effective in 1945. Some of the experimentalists who were involved in the war effort during these years felt that this transformation of the APA was effected to their detriment while they had no opportunity to participate in APA affairs.

\section{Organizations of Experimentalists}

It did not take long after the founding of the APA for experimentalists to begin their long history of efforts to organize separate groups within or outside of the new organization. In 1898, just 6 years after the APA was founded, Lightner Witmer, the University of Pennsylvania psychologist celebrated as the founder of the first psychological clinic, initiated an effort to form an organization of laboratory-based psychologists to be independent of the APA (Goodwin, 1985). The effort failed, and Edward B. Titchener, the structuralist psychologist and head of the laboratory at Cornell University, was partially responsible. A number of issues were involved in Witmer's attempt, but the perceived domination of the APA by individuals other than experimentalists was pivotal.

The Experimentalists. Titchener would wait another 6 years before founding his own group, popularly known as the "Experimentalists" (Boring, 1938, 1967). Titchener wanted a smaller meeting of representatives from different laboratories who would meet in a laboratory and could handle the apparatus there. They would exchange frank criticisms in a smoke-filled atmosphere that would exclude women. The first meeting was held at Cornell in April 1904. After that, the meetings rotated among various laboratories in the northeastern United States. Although a core of laboratories was to be invited, the host exercised some freedom in determining both the guest list and some aspects of the format of the meetings. As the meetings began to get larger, forcing some changes of format, it became apparent that various changes needed to be made. This happened fairly soon after Titchener's death in 1927.

The Society of Experimental Psychologists. A committee was appointed to form a society that would continue the tradition of the informal Experimentalists. An initial five-man committee was expanded to 15,10 of whom met at Princeton University in 1929 to found the Society of Experimental Psychologists (SEP). Membership would be open to men and women but be limited to North American psychologists. There were 26 charter members. Membership would be limited to 50 , with election to membership intended as a distinct honor. The purpose was to hold informal meetings for the discussion of results of experimental investigations (Boring, $1938,1967)$. The group continues until this day, providing a forum for experimental psychologists and an honor to those elected to membership.

It is noteworthy that the 10 full members of the Organizing Committee of the Psychonomic Society were all members of the SEP. The similarity between these two organizations was not lost on Boring:

In 1960 its 18,215 members so swamped the APA's experimentalists that they formed an independent Psychonomic Society which began with a bang - 736 members all looking for what Titchener was seeking in 1904 - an intimate group for friendly scientific discussion. (Boring, 1967, p. 325) 
Experimentalists' conferences at the American Psychological Association. A little-known effort to improve communication among experimental psychologists within the APA was initiated in the 1920s by two of Titchener's former students, Edwin G. Boring of Harvard University and Karl Dallenbach of Cornell, together with Samuel W. Fernberger of the University of Pennsylvania (Goodwin, 1992). The feeling was that the APA sessions were becoming too dominated by applied interests and that something had to be done to make the experimental sessions more attractive. They devised the plan whereby the last day of the 1923 APA meeting in Madison, Wisconsin, would be devoted to an "experimentalists session." It is clear that Titchener's Experimentalists were the model, and there was concern that the new effort might hurt Titchener's group. The initiating group was enlarged to include J. E. Anderson of Yale University, Raymond Dodge of Wesleyan University, E. S. Robinson of the University of Chicago, and John F. Shepard of the University of Michigan. Invitations were sent by the group on September 12, 1923 (Anderson et al., 1923). The group wrote that:

\begin{abstract}
In the belief that the annual meetings of the American Psychological Association could be made much more useful to experimental psychologists, the members of the Association named below ... have ventured to suggest purely as a trial performance that the last day of the Madison meeting be set aside for an "Experimentalists Session."... It is thought best that the meeting should be informal, that there should be no set papers, and that the time be devoted to a discussion of the work being carried on in various laboratories." (Anderson et al., 1923)
\end{abstract}

The first Conference, held on December 29, 1923 in Madison, was a success. It was attended by some 40 people, including such stalwarts as Harvey Carr, Clark Hull, Joseph Jastrow, H. C. Warren, and Robert S. Woodworth. The organizing committee was expanded, and Boring organized a conference for the Washington meeting of 1924 . The conferences continued for 5 years, with their size increasing from year to year until they began to lose their early, easy informality. There was no separate 1929 APA meeting because of the International Congress of Psychology in New Haven. The experimental conferences were not resumed, however, when the APA meetings resumed. Perhaps the very success of the conferences set the stage for their demise, as they lost their small, informal character. The success of the conferences helped illustrate the fact that experimental psychology was not in such dire straits as some had proclaimed.

As with the breakaway groups discussed earlier, one sees parallels between this effort of the 1920s and the early organizational efforts related to the Psychonomic Society.

The Psychological Round Table. In the 1930s, a rebellious group of younger psychologists felt that the APA meetings were not meeting their needs and, more importantly, that they were excluded from the prestigious Society of Experimental Psychologists because they were too junior. Their response was to form a new group di- rected at the SEP, the Psychological Round Table (PRT) (see Benjamin, 1977). Although the group had been provisionally called the Society of Experimenting Psychologists, as a parody on the aging, and relatively inactive, members of the Society of Experimental Psychologists, some SEP members objected, and cooler heads in the new group modified the name. The organizational steps were precipitated in the aftermath of the 1936 APA meeting at Dartmouth College, which S. Smith Stevens and Edwin B. Newman, both of Harvard University, deemed rather ponderous. They were joined by Clarence $\mathrm{H}$. Graham of Brown University, William A. Hunt of Connecticut College for Women, and Carlyle Jacobsen and Donald G. Marquis of Yale University in inviting a group of young, northeastern, male experimental psychologists to an informal meeting.

The purpose of the organization was to provide a small forum for the discussion of recent research. The PRT was run informally by an "Autocratic Minority," also known as "the Dictators" or "the Secret Six," who organized the meetings and invited the participants. Meetings were held in small New England towns and were quite casual. The ability to socialize and have a good time were as important to being invited back as was the ability to present good research. However, invitations to attend the meetings ceased when one reached the age of 40 .

Despite the light-hearted aspects of the group, its membership over the years came to include many of the nation's leading experimental psychologists, and it became a feeder for the Society of Experimental Psychologists, for the National Academy of Sciences, and for positions on the faculties of major universities (see Benjamin, 1977, for more details). Six of the 10 members of the Organizing Committee of the Psychonomic Society were alumni of the PRT, and some characteristics of the Psychonomic Society can be recognized as extensions of features of the earlier group.

The PRT was limited to psychologists from the Northeast for practical reasons of travel and scheduling. In 1959, a midwestern equivalent group, the GUV (Gesellschaft für Unendliche Versuche, or Society for Endless Research) was founded by E. James Archer, George E. Briggs, John W. Cotton, Ward Edwards, Charles W. Eriksen, and Ira Hirsh, several of whom had attended the PRT meetings. It had a membership limit of 40 and an age limit of 40 years. A group of six "GUVernors" led by a "Schriftführer," ran the group (Benjamin, 1977; Naylor, 1994).

Other efforts. Dissatisfaction of experimental psychologists in the APA continued and indeed seemed heightened after the reorganization of the APA. Thus, in 1948, just 3 years after the adoption of the divisional structure, Kenneth W. Spence and Clarence H. Graham initiated an effort to remove Division 3 (Experimental Psychology) from the APA (Spence, 1959). It failed.

Many smaller organizations of psychologists have been developed in the interim, dramatically changing the characteristics of the primary avenues of communication in the field. The latest separatist movement among sci- 
entific and academic psychologists culminated in the founding of the American Psychological Society in 1988.

\section{THE BEGINNINGS OF THE PSYCHONOMIC SOCIETY}

\section{Forming an Organizing Committee}

With that background, we return to the 1950s. In that bar in Washington where the plot to form a new organization was being hatched during the 1958 AAAS meeting, the discussants agreed that what was needed was a group that was smaller, more select, and less formal than the APA, where new data and ideas in the experimental areas of psychology could be explored in a more congenial atmosphere. They decided that the time had come to get organized. There was much discussion at the meeting and after. However, it appears as though all returned to their home universities and went about their business with relatively little happening until the next summer. There was discussion of the organizational plans at a meeting of the Society of Experimental Psychologists hosted by Wendell R. Garner in Baltimore, Maryland, in the spring of 1959 (Humphreys, 1994). A brief chronology of the events that ensued is presented in Table 1.

At the time of the 1958 meeting, Verplanck was in the midst of a job transition; he had resigned from Hunter and would be moving to the University of Maryland in the fall of 1959 (Verplanck, 1991), and he would spend

Table 1

A Chronology of the Founding of the Psychonomic Society

December, 1958. Discussion in a bar in Washington, DC during the AAAS meetings including at least Graham, Morgan, Stevens, and Verplanck.

July 4,1959 . The first letters from University of Wisconsin faculty are sent to prospective members of an Organizing Committee.

July 23, 1959. Membership on the Organizing Committee has reached 8 (Brogden, Estes, Graham, Morgan, Neff, Spence, Stevens, and Underwood) plus Secretary-Treasurer Verplanck; Geldard and Humphreys are soon added.

August 1, 1959. A letter to prospective members of the "American Federation of Experimental Psychologists" is sent by the Wisconsin faculty members.

December 29-30, 1959. Meeting of the Organizing Committee, Morrison Hotel, Chicago. Bylaws are worked out and the nature of the new society is shaped.

December 31, 1959. The new society is declared established.

March 30, 1960. Membership is at 510.

March 31-April 1, 1960. First (informal) meeting of the Governing Board of the Psychonomic Society is held in Madison, WI.

April 1, 1960. The Psychonomic Society is incorporated in the State of Wisconsin.

September 1, 1960. Second meeting of the Governing Board of the Psychonomic Society is held.

September 1-3, 1960. First Annual meeting of the Psychonomic Society is held at the University of Chicago.

December 15, 1960. Membership is at 772 .

December 31, 1960. First Newsletter published. the summer of 1959 teaching at the University of Wisconsin, Madison. Morgan himself was due to arrive in Madison for the fall quarter. Because the "conspirators" believed that the Wisconsin experimentalists would be sympathetic to the idea of a new society, it was agreed that Verplanck would do the spade work of initiating movement toward the new society. Morgan, Stevens, Graham, and others all agreed to do what they could to help.

Verplanck committed himself to the formation of the new society as his primary effort of the summer besides teaching his courses. He got good moral support from his colleagues in Madison, including departmental chair Jack Gilchrist, and was given secretarial help and mailing privileges in the Department of Psychology. The first step would be the formation of an Organizing Committee, and there was much discussion at coffee time about who should be invited to serve on it. Brogden, Grant, Mote, and Verplanck were most active in identifying the psychologists to be invited to become members of the Organizing Committee.

Perhaps it is significant that the initial letters of invitation were sent out on Independence Day, July 4, 1959. They went to William K. Estes of Stanford University, Frank A. Geldard of the University of Virginia, Clarence H. Graham of Columbia University, Neal E. Miller of Yale University, Clifford T. Morgan of The Johns Hopkins University, William D. (Dewey) Neff of the University of Chicago, Kenneth W. Spence of the State University of Iowa, S. S. Stevens of Harvard University, and Benton J. Underwood of Northwestern University. Wilfred S. (Wulf) Brogden had already agreed to be the Wisconsin representative on the Organizing Committee. Brief sketches of the members of the initial Organizing Committee can be found in Table 2. Those signing the letters were all from the Wisconsin department: E. James Archer, W. S. Brogden, J. C. Gilchrist, David A. Grant, Herschel W. Leibowitz, F. A. Mote, Karl U. Smith, Willard R. Thurlow, William S. Verplanck, and L. Benjamin Wyckoff, Jr. Harry F. Harlow, who would become a charter member, was elsewhere on campus and not involved in the organizational activity. This group of Wisconsin psychologists should be credited with providing the initial impetus and stature for the development of the new society.

Some correspondence from this initial, organizational phase of the Organizing Committee is preserved in the Archives of the History of American Psychology at the University of Akron in Akron, Ohio. Each prospective member received a letter of invitation and a draft letter to be sent to prospective charter members of the American Federation of Experimental Psychologists, as it was called at this time. Clearly, perceived problems with the APA were foremost in the minds of the organizers. The main letter opened with a reference to the 1948 attempt to remove Division 3 (Experimental Psychology) from the APA and to an APA publication dealing with Graduate Education in Psychology (Roe, Gustad, Moore, Ross, \& Skodak, 1959), which was thought inappropriate, because it was perceived as an attempt by the APA to dic- 
Table 2

Membership of the Organizing Committee of the Psychonomic Society, 1959

Wilfred J. (Wulf) Brogden, 47, University of Wisconsin. b. Sydney, Australia May 6, 1912. d. Madison, WI, February 22, 1973. PhD University of Illinois, 1936. Experimental psychology, conditioning, and motor learning.

William K. Estes, 40, Stanford University. b. Minneapolis, MN, June 17, 1919. PhD University of Minnesota, 1943. Human and animal learning, behavior theory, quantitative methods.

Frank A. Geldard, 55, University of Virginia. b. Worcester, MA, May 20, 1904. d. December 8, 1984. PhD Clark University, 1928. Psychophysiology of vision, cutaneous senses.

Clarence H. (Clancy) Graham, 53, Columbia University. b. Worcester MA, January 6, 1906, d. New York, NY, July 25, 1971. PhD Clark University, 1930. Physiological optics, perception, conditioning.

Lloyd G. Humphreys, 46, University of Illinois. b. Lorane, OR, December 12, 1913. PhD Stanford University, 1938. Conditioning, individual differences, measurement.

Clifford T. Morgan, 44, University of Wisconsin, Madison. b. Minotola, NJ, July 21, 1915. d. Austin, TX, February 12, 1976. PhD University of Rochester, 1939. Physiological psychology and engineering psychology.

William D. (Dewey) Neff, 47, University of Chicago. b. Lomax, IL, October 27, 1912. PhD University of Rochester, 1940. Brain function, neural mechanisms of sensory discrimination, physiological acoustics.

Kenneth W. Spence, 52, State University of lowa. b. Chicago, IL, May 6, 1907. d. Austin, TX, January 12, 1967. PhD Yale University, 1933. Learning and motivation, theory of conditioning and learning, scientific method in psychology.

S. Smith (Smitty) Stevens, 53, Harvard University. b. Ogden, UT, November 4, 1906. d. Vail, CO, January 18, 1973. PhD Harvard, 1933. Psychophysiology of hearing, constitutional psychology, psychoacoustics, theory of measurement.

Benton J. Underwood, 44, Northwestern University. b. Center Point, IA, February 28, 1915. PhD State University of lowa, 1942. Human learning and retention.

William S. Verplanck, 43, University of Maryland. b. Plainfield, NJ, January 6, 1916. PhD Brown University, 1941. Experimental analysis of behavior, behavior theory, animal behavior, thinking and concept formation (Secretary-Treasurer).

Primary Source: American Men of Science (10th ed., 1960-1962).

tate what courses would be taught in graduate programs. This was viewed as a further intrusion by the APA into matters inappropriate for a scientific organization. By contrast, the new society would have just two purposes. One would be to conduct annual meetings to disseminate results of recent research in experimental psychology, and the other would be to begin journal publication. The possibility was raised that support might be sought from the National Research Council or the National Science Foundation. Recipients were asked for additional nominations for the Organizing Committee and for the position of Acting Secretary.

The first positive reply, dated July 9 , was sent by Neff. Morgan and Spence replied the next day. Morgan noted that he would "jump at the chance to be a member of the organizing committee" (Morgan, 1959a). Graham replied affirmatively in a postcard from London on July 13 . Stevens, who had been hospitalized, Underwood, who had been in California, and Estes replied soon thereafter. Underwood was concerned about the plan to request foundation support. By the time that reminder letters went out on July 23, there was an eight-man committee. Geldard's acceptance left only Miller as a dissenter. Geldard was concerned that it be made clear that members of the new society expected to remain in APA and to support Division 3.

On August 1 the Wisconsin group, using letterhead with the names of the eight Organizing Committee members, sent out a letter to prospective members of the American Federation of Experimental Psychologists. The intent of the letter and its enclosures was to inform a broader community of the events that were transpiring and thus to lay the groundwork for support.

Following the suggestions from the initial invitees, six additional psychologists, Frank A. Beach of the University of California, Berkeley, Robert M. Gagne of Princeton University, Lloyd G. Humphreys of the University of Illinois, Donald B. Lindsley of the University of California, Los Angeles, Roger B. Loucks of the University of Washington, and Carl Pfaffmann of Brown University were invited to join the Organizing Committee on July 14. Of this group, only Humphreys immediately joined the Organizing Committee. Humphreys had reservations because he wanted a stronger break with the clinicians, but he joined the committee anyway. Thus, 10 of the 16 invitees accepted the invitations. Verplanck, who emerged as the Secretary-Treasurer of the group and was pivotal in its formation, was not counted as a member of the Organizing Committee.

The Organizing Committee was composed of individuals with diverse university affiliations and research interests (see Table 2). All, however, were part of the ingroup network of prestigious experimentalists. All were white male PhDs between the ages of 40 and 53. Both Geldard and Graham were born in Worcester, MA, the birthplace of the APA. All full members of the Organizing Committee were members of the Society of Experimental Psychologists. In 1960, Graham, Spence, and Stevens had already been elected to the National Academy of Sciences; Estes, Neff, and Underwood would be added later. Six of the 10, Brogden, Graham, Humphreys, Morgan, Neff, and Stevens, were alumni of the Psychological Round Table, as was Verplanck.

The negative responses to the Organizing Committee are interesting as well. Like Humphreys, Gagne wanted a strong dissociation from psychology as then perceived in the mind of the public. He emphasized the importance of some kinds of applied work but wanted to distance himself from those trying to cure mental illness. Beach, Miller, and Pfaffmann all resisted the appearance of a split from APA, feeling that the group's goals could be met within Division 3. Miller, about to become the APA President, was sympathetic with the frustrations of the group, and indeed shared them, but felt that the new group would not really help experimental psychology. Beach expressed a number of reservations, including a concern for the well-being of the APA. He was especially concerned that the new organization would establish the elaborate 
machinery of the old one, a concern that turned out to be unfounded. Pfaffmann too was concerned with the divisiveness of the effort, but noted that he did better by attending physiological, rather than psychological, meetings already. The replies to these letters of concern, written by Verplanck and his Wisconsin associates, were thoughtful and forced their authors to sharpen the focus of their goals and intentions, but they failed to convince the dissenters. Meanwhile, Wisconsin psychologists William A. Mason, Leonard E. Ross, and James M. Vanderplas, learning of the effort, joined in signing these replies by the Wisconsin group. As of November, Lindsley, who was quite busy with other matters at the time, had not replied, but he was elected to the Governing Board soon after the Psychonomic Society was established. Apparently, Loucks never replied.

There was thus a range of views about the need for a new organization as opposed to the utility of trying to work within the APA. As may often be the case when new organizations are formed, those who were most zealous in their opposition to the old organization did most of the nitty-gritty work of establishing the new organization. The less zealous followed along without taking the lead.

Although an organizational committee had been established, it was as yet undifferentiated and without leadership. That would soon change. Verplanck (1959b) wrote to Morgan encouraging him to become the Secretary when the Organizing Committee met. At this point, Morgan assumed leadership and some degree of control. He replied (Morgan, 1959b) that he would prefer that Verplanck, who was not even a member of the Organizing Committee, appoint him as the bylaws committee. Morgan reasoned that "the bylaws represent the crux of getting a new organization going" and that he was experienced in such work. Toward that end, Morgan enclosed material, entitled "Some Thoughts on the Need for a Society of Research Psychologists," that he had already drafted that could form as the basis for a set of bylaws (Morgan, 1959c). In an apparent effort to leave the impression that power had been bestowed rather than assumed, he added "you might say that you asked me to see what I could do about drafting some bylaws, and that the essay is a trial balloon" (Morgan, 1959b). Verplanck (1959c) agreed to distribute the essay to the Wisconsin group and later to the Organizing Committee. A "war council" (Verplanck, 1959d) met and decided to raise issues of the character of Division 3 meetings and proposals for a new organization at the forthcoming APA convention.

At about this time, the APA's Board of Scientific Affairs issued a document that would be frequently cited as the new society was being organized (Board of Scientific Affairs, 1959). In an article in the American Psychologist, the Board, which included no members of the Organizing Committee, addressed the need for improved communication of scientific information, judging "the problem of efficient and effective communication of scientific information to be perhaps the most critical problem faced by scientific psychology today" (Board of Scientific Affairs, 1959, p. 270). Morgan (1959c), and later others, used the report as a springboard for the need for a new society.

\section{Toward a Meeting of the Organizing Committee}

With travel and the relocation of two key members of the Organizing Committee, Verplanck to the University of Maryland and Morgan to Wisconsin, there followed a bit of a lull in activity. Frederick Mote (1959), at Wisconsin, filled in Verplanck concerning the discussions about the proposed new society that had occurred at the 1959 APA meeting. Apparently, there was little interest, but Division 3 did decide to send out a straw-vote questionnaire regarding its meetings and the possibility of dissociating them from the rest of the APA convention.

Efforts to organize what was now being called the "New Society" resumed in November. On November 27, Morgan sent out a call to a meeting of the Organizing Committee in association with the AAAS meetings to be held in Chicago on December 29-31, 1959. Morgan enclosed a checklist of questions about the New Society, a new draft letter of invitation for charter members, a new version of his earlier essay, and a rough draft of bylaws.

\section{The Meeting of the Organizing Committee}

The Organizing Committee met on December 29 and 30 at the Hotel Morrison in Chicago. Those attending were Geldard, Humphreys, Morgan (acting chairman), Neff, Spence, and Underwood, with Verplanck as acting secretary. These seven men, a "Chicago Seven" of the Psychonomic Society, were responsible for shaping the New Society in most of its significant aspects and may be regarded as its architects. Brogden, Graham, and Stevens were unable to attend but sent written comments and suggestions (Verplanck, 1959d); Estes did not participate because of the timing of the meeting.

The 2 days of meetings in a smoke- and whiskey-filled room were devoted to hammering out the bylaws. In the process, the unique character of the Psychonomic Society was shaped. An eyewitness account of the meeting, provided by Verplanck and Humphreys, is presented in Appendix D. There was much debate, but it was a debate among equals. Decisions were made concerning the membership, the nature of the meetings, the form of governance, and the possibility of journal publication; each of these issues will be discussed below. A consensus was indeed hammered out in most instances, although no decision was yet reached regarding the New Society's name. The name "Psychonomic Society" was subsequently adopted by correspondence between February 1 and March 29, 1960. Each member of the Organizing Committee contributed $\$ 10$ as a loan to get the New Society started.

By the end of the meeting, Morgan was elected the first Chairman of the New Society and Verplanck the first Secretary-Treasurer. "The members of the OC became members of the Governing Board and the Society was declared founded" (Verplanck, 1959d). The date of the founding of the New Society was listed as December 31, probably because the December $\mathbf{3 0}$ meeting finished after 
midnight. Terms on the Governing Board were arranged to end in a staggered fashion: those of Geldard and Graham, in 1960; Spence and Stevens, 1961; Brogden and Neff, 1962; Humphreys and Underwood, 1963; and Estes and Morgan, 1964.

\section{Invitations to Join}

Some "950-odd" (Verplanck, 1960b) invitations to charter membership (see Appendix B) were soon sent out according to procedures to be described below. As of March 30, the fledgling Psychonomic Society had 510 charter members. By July 23, there were 720 members, 469 of whom had paid dues.

\section{The First (Informal) Meeting of the Governing Board}

Following the pattern of meeting in association with larger organizations, the first (informal) meeting of the Governing Board, meeting as a Governing Board, was conducted in association with the meetings of the Society of Experimental Psychologists in Madison on March 31 and April 1, 1960. All members of the Governing Board except Spence and Stevens were in attendance (Verplanck, 1960c). All except Verplanck were also in attendance as members of the SEP (Kennedy, 1960). Many of the issues addressed in Chicago were revisited and resolved at the Madison meeting. The primary concern was the organization of the first scientific meeting, scheduled for the following September in association with the APA meetings in Chicago. Underwood agreed to take charge of the program, and Neff of local arrangements for the Chicago meeting. Underwood would also chair the Membership Committee, with Estes and Graham as members. Matters of incorporation, membership, publications, and possible affiliations were also discussed.

Working with a lawyer engaged by Brogden, THE PSYCHONOMIC SOCIETY, INC. was incorporated in the State of Wisconsin on April 1, 1960. Brogden was the initial registered agent. An announcement of the new organization was prepared for publication in the American Psychologist (Brogden et al., 1960).

\section{The First Annual Scientific Meeting of the Psychonomic Society}

The first meeting of the Psychonomic Society was held at the University of Chicago on September 1-3, 1960, just before the 1960 APA meetings. Approximately 294 individuals attended, of whom 195 were members, 79 were guests, and approximately 20 were unregistered. The program included 119 papers in 24 sessions arranged in eight time blocks with three concurrent sessions each; four blocks on Thursday, three blocks and an afternoon business meeting on Friday, and one block on Saturday morning. They were grouped into 15 categories. The nature of the experimental psychology of the time, at least for the members of the new Psychonomic Society, can be seen in the distribution of papers across sessions; these are presented in Table 3.
Table 3

Summary of the Program at the First Meeting of the Psychonomic Society, September 1-3, 1960, Chicago

\begin{tabular}{lcc}
\hline \multicolumn{1}{c}{ Topic } & No. of Sessions & No. of Papers \\
\hline Audition & 1 & 7 \\
Brain Functions and Learning & 1 & 5 \\
Conditioning & 2 & 7 \\
Discrimination Learning & 1 & 5 \\
Drive and Reward & 3 & 19 \\
Equipment Development & 1 & 3 \\
Genetic & 1 & 6 \\
Human Learning & 2 & 9 \\
Information Processing & 2 & 8 \\
Mathematical Models & 2 & 10 \\
Methods & 2 & 7 \\
Partial Reinforcement & 1 & 6 \\
Potpourri & 1 & 2 \\
Quantitative & 1 & 6 \\
Vision & 3 & 19 \\
Total & 24 & 119 \\
\hline
\end{tabular}

Since the meeting opened with three concurrent sessions, three sets of authors share the honor of presenting the first paper at the Psychonomic Society meetings: A. Leonard Diamond on "The reticular system and the visual brightness response," Delos D. Wickens and Joyce Kasner on "Inferiority of conditioning to a $10 \mathrm{cps}$ visual CS," and Peter W. Hemingway and Charles Wrigley on "Multiple agreement analysis: A method and logic of psychological classification based on configurations of responses."

Brogden ("Contiguous conditioning"), Morgan ("Increment thresholds for monochromatic stimuli with selective color adaptation of the eye"), and Stevens ("The brightness function: Effects of adaptation and contrast") were the only organizers to present papers. Brogden, Humphreys, Morgan, Stevens, Underwood, and Verplanck chaired sessions.

Lawn-sitting, moon-viewing, and issue-settling in the Courtyard of the New Residence Hall were also popular both in the late afternoon and evening. The large consumption of coffee and ice cubes made available by the arrangements committee attest to the success of this phase of the meetings. (Verplanck, 1960e, p. 2)

Although most found the program invigorating, it was not really significantly more substantial than what could be found at the APA meetings. Members of several APA divisions were involved in the Psychonomic Society. Consider the APA program for just Division 3, the division most prominent in the Psychonomic Society's development. At the 1959 APA meeting, to which many were reacting, Division 3 sponsored 31 sessions with 39 hours of programming. This allowed for the presentation of 131 papers, plus 4 hours of material in sessions on the Experimental Analysis of Behavior that were listed in the program with speakers to be announced, plus a Presidential address by Estes and a business meeting. The 119 papers in 24 sessions at the Psychonomic Society were roughly comparable. Thus, although the atmosphere at 
the new meeting may have been unique, the size of the program was not.

\section{The First Business Meeting}

The first general business meeting was held on Friday, September 2, 1960 at 4:15 p.m. Morgan gave the opening address, beginning

Fellow psychonomists and psychonomers! I welcome you to the first annual meeting of the Psychonomic Society. (Morgan, 1960b)

Fortunately, a nearly complete copy of the address survives (Morgan, 1960b). The talk consisted of a summary of the events leading to the formation of the Psychonomic Society and the rationale underlying the pivotal decisions made by the Organizing Committee and the Governing Board. Morgan presented a clear summary of the logic underlying the Psychonomic Society and the decisions hammered out by the Chicago Seven. The address was followed by a business meeting, in which the nittygritty organizational matters of the Psychonomic Society were reviewed (Verplanck, 1960e). "No new business was proposed from the floor; there was some comment from members on the hopeful future of the Psychonomic Society."

\section{The Second Meeting of the Governing Board}

The Governing Board met on September 1, with Brogden, Estes, Humphreys, Donald Lindsley, Morgan, Neff, Stevens, Underwood, and Verplanck in attendance (Verplanck, 1960d). David A. Grant, of the University of Wisconsin, and Donald B. Lindsley, of the University of California at Los Angeles, had been elected to the Governing Board for terms 1960-1965. Geldard and Graham, whose terms were set to end in 1960, were reelected, bringing the size of the Governing Board to 12 .

\section{The First Newsletter}

The first newsletter was published on December 31, 1960 , a year to the day after the Society had been founded (Verplanck, 1960e). As of December 15, membership stood at 772 . The membership was brought up to date on the current state of the Psychonomic Society with an emphasis on the events transpiring at the first annual scientific meeting. The Psychonomic Society was on its way.

\section{SHAPING THE PSYCHONOMIC SOCIETY}

During the 2-year period just described, the Psychonomic Society took shape - a shape that has persisted in its major aspects until the present. Certain issues were addressed and resolved over time rather than at any one particular meeting. We turn now to discussions of some of those issues.

\section{The Need for a New Society}

From its beginning, the new society was formed in reaction to developments in the APA. The reorganization of the APA had strengthened the role of practice-oriented psychologists and exacerbated the disaffection felt by the hard-nosed experimentalists. For these experimentalists, psychology had to be first and foremost a science. Perhaps the clearest early statement of the need for a new society appears in the reply drafted by Verplanck, in the name of 10 Wisconsin psychologists, in response to Frank Beach's concerns about a new society (Verplanck, 1959a). Although there was a long list of developments that annoyed the group, concern number one was the annual meeting, which was becoming more problematical. One APA committee had recommended that no contributed papers be allowed at the meeting. An extremely important irritant was the decision by the APA that in 1959 there were to be no slides allowed at the annual convention. Estes (letter to H. L. Roediger III, December 1, 1994) recalled:
More than any one incident or action, that decision alarmed the experimental psychologists, who saw it carrying the message that the APA was entering a rapid process of dis- sociating itself from the support of the scientific portion of the convention.

Estes, who was preparing a Division 3 presidential address when the decision was announced, recalled littering his rented California house with enormous sheets of paper on which he drafted graphs to be used as posters to illustrate his talk in lieu of slides. He recalled:

I also constructed a rack to hold the posters and the assem-
bled material was carried on the roof of our station wagon,
first back to our home in Indiana in late August and then
to the site of the convention where the exceedingly cum-
bersome process of illustrating my address to Division III
with posters dramatized the reaction of myself and a great
many others to the APA's decision about visual aids. I
doubt that any one event did as much to stir up several hun-
dred experimental psychologists to the point that they were
eager to sign up as charter members of the about-to-be-
formed Psychonomic Society.

At this point, the planners were not sure just how the new society would provide an improvement, but they were sure that it would. In written statements, they emphasized that the new society would complement, not replace, the APA. "We do not conceive that this organization will be a competitor with or threat to the APA. It will perform those functions of a scientific society that APA has let go, willy nilly, by default" (Verplanck, 1959a). Some members of the new society, however, took a different view, wishing it to replace the APA as an organization of scientific psychologists.

By the time that letters of invitation went out to prospective charter members, there were "two purposes: (1) to arrange for, and to conduct, appropriate annual meetings for the dissemination of results of recent research in scientific psychology; and (2) if it should prove desirable, to produce media in which papers reporting such research can be published" (Morgan, 1960a).

The mature statement appeared in Morgan's opening address at the first business meeting. He expressed his 
view, working in "science" and its derivatives six times in a single sentence.

\begin{abstract}
We did it primarily because we wanted meetings like this one, meetings with a low noise level, meetings of some serenity and dignity, meetings attended by people with a common interest in communicating with each other about science, meetings where it is possible to see and talk with one's scientific friends without stumbling over people with "patients," meetings not dominated by program committees who subordinate original scientific papers to symposia or who tell you you can't have slides, meetings without press rooms and book stalls-in short just plain scientific meetings attended by scientists talking about science. (Morgan, 1960b, p. 2)
\end{abstract}

After addressing a variety of issues, Morgan emphasized the desire not to hurt the APA:

We have chosen to remain independent of APA so that our hands will not be tied in anyway [sic]. On the other hand, we have no desire to hurt it, and we should, and will, cooperate with it to insure that both societies serve well the purposes for which they were intended. (Morgan, 1960b, p. 14)

\section{What's in a Name?}

The problem of naming the new society was among the more intractable ones faced by the Organizing Committee. The initial, provisional title was the "American Federation of Experimental Psychologists." Although Graham fought for this name, the majority felt it too faceless, in that it appeared to be derivative, a parallel to the American Federation of Experimental Physiologists, and it appeared eminently forgettable. The organizers wanted a name that was unique and easily identifiable. For a time, the fledgling organization became known simply as the "New Society."

The Organizing Committee agonized over the name at its 1959 meeting but was unable to reach a resolution. The six members assembled split between "Psychobiological Society" and "Psychonomic Society," with three votes each (Verplanck, 1960a). The group left Chicago with three names still on the table, "Psychological Research Society," "Psychobiological Society," and "Psychonomic Society."

For the latter, they cited Webster's Unabridged Dictionary. One such dictionary of the time, Webster's New International Dictionary (Nelson, 1956) carries a definition of psychonomic as "pertaining to the laws of mental life" and psychonomics as "the science of the laws of the mind; psychology" (p. 2002).

The organizers left Chicago with the agreement that Neff would consult a linguist to provide a fourth alternative. Verplanck would then send out two ballots, the first to get the choices down to two alternatives and the second to choose the final name. After consulting a professor of Greek, Neff (1960) came up with six possibilities: bionomy or bionomics (from bios, meaning life or manner of living), praxilogy or praxinomics (from praxis, meaning a doing, transaction, action, conduct), noology (from nous, meaning mind or brain), psychobiotics, psycho- nomics, and biopsychology. Verplanck, too, consulted a Professor of Greek, who, given the definition of "behavior," recommended the word bios as the precise term in Greek (Verplanck, 1991). There was some sentiment for the word bios, but it had been preempted by biologists.

We have not located correspondence related to the actual vote. As late as February 1, 1960, it was still the New Society. However, the term Psychonomic Society appeared on the invitations to prospective charter members in time for 510 to join by March 30. The name must have been settled soon after February 1. On April 1, incorporation led to the complete name The Psychonomic Society, Inc.

Morgan summarized the struggle in his opening address in Chicago. He noted that there had been some interest in noology. Colleagues, however, suggested that it connoted "something all freshman girls should have a course in" (Morgan, 1960b, p. 4). The name was dropped.

The group was not fully happy with the science of "mind," but appeared worn out by the struggle. Morgan (1960b) noted that "if astronomy and psychonomy are siblings, then of course so are astrology and psychology" (p. 4). The analogy of psychonomy being to psychology as astronomy is to astrology would be oft repeated. The lone known copy of Morgan's talk is missing page 5. In the talk, Morgan credits Humphreys with the analogy and begins to fill in the story of its origins when the text reaches the missing page. The full origin of the analogy may never be known.

In actuality, there is more of a history to the term psychonomic and its congeners than the founders were aware of. Some of the earlier uses are discussed in Appendix C.

\section{Membership Matters}

Among the most central questions for any organization is the issue of membership, which defines the organization. This issue proved the most contentious at the Chicago meeting of the Organizing Committee, as recalled by Verplanck (personal communication, October 27, 1994; Appendix D). There was a conflict of values. Some, like Morgan and Stevens, wanted a frankly elitist organization, something like the Psychological Round Table. Others, like Humphreys and Spence, wanted a more open, democratic organization, within which unsponsored graduate students could present papers. This raised the issue of quality control. Was there a way to both maintain high standards and be open, progressive, and forward looking? A consensus eventually was reached on this issue. As stated in the bylaws (Appendix A), "to be eligible for membership, a person must hold the Ph.D. degree or equivalent, and must have published significant research other than the doctoral dissertation." The latter stipulation was critical and hearkens back to membership requirements in the APA prior to 1925. Nominations of prospective new members would be made to the Governing Board, which would vote on the nominees. Once approved for membership, nominees would be free to present or sponsor a paper at each scientific meeting.

A particular concern was that nonpsychologists, such as those trained in sensory physiology, should be wel- 
come. A special effort was made to include such scientists and to invite them to full membership.

It is notable that there would be no Fellows elected; this was to be an organization of peers.

Procedures for inviting prospective charter members were agreed upon (Verplanck, 1959d). They read like a typical product of an academic committee. Verplanck was to send membership lists for Divisions 1, 3, 5, 19, and 21 of the APA to each of the members of the Organizing Committee. Each would check names of those he wanted to nominate as charter members and add the names of others he wished to nominate. This was to be done within 1 week of receipt of the lists. All names appearing on two or more lists were to be invited to charter membership. A list of those nominated only once would be circulated to the committee members who would scratch out the names of those they thought unqualified. The names on that list who did not receive two or more objections would be invited.

Invitations were duly issued and the membership grew -510 by March 30, 720 (469 of whom had paid dues) by July 23, and 772 by December 15,1960 .

Charter membership was limited to those nominated by the Governing Board according to the procedures just outlined. Additional members could be nominated by any member of the society. Membership forms were drawn up and included space for the listing of four publications.

Morgan (1960b) explained the decisions concerning membership to those assembled in Chicago. He was concerned that for psychologists as a whole "the modal number of postdoctoral publications is zero" (p. 6). Thus, if they did not require research beyond the doctorate as a prerequisite for admission, sooner or later 90 percent of our members would be people who had so little interest in science that they never completed and published research after they got out of graduate school. Reflecting on this, we thought we knew why the APA became what it has become-if you know what I mean. (p. 6)

Surely the comment was met with chuckles from the audience. Morgan added:

We are not trying to be exclusive. We just want to make sure that we have a scientific society and that it stays one. (p. 6)

At the time of the September 1960 business meeting in Chicago there were 736 members. Verplanck (1960e) analyzed the membership with regard to their APA affiliations. His results are reprinted here as Table 4 . The heavy emphasis of Division 3 (Experimental Psychology) membership is apparent. It should be recalled that at this time Division 6 (Physiological and Comparative) was amalgamated within Division 3.

Analysis by gender is difficult, because some members were identified only by initials and some had names not clearly identifiable by gender. A rough estimate is that approximately 38 of the first 736 members $(5.2 \%)$ were women. This may be an underestimate. None were on the Organizing Committee.

Although several membership lists have been preserved, none can be definitively identified as the final list of charter members.

\section{What Kind of Meetings?}

It was in shaping the annual meetings that problematic experiences with the APA seem to have been most influential; the Committee tried to make the meeting as different from those of the APA as possible. After all, the

Table 4 An Analysis of the Membership of the Psychonomic Society in 1960

\begin{tabular}{|c|c|c|c|}
\hline Group & $N$ & $\begin{array}{c}\% \text { of Total } \\
\text { Psychonomic Society } \\
\text { Membership }\end{array}$ & $\begin{array}{l}\% \text { of Total Number of } \\
\text { Fellows or Members of } \\
\text { the Given Division }\end{array}$ \\
\hline Nonmembers of APA & 41 & 6 & \\
\hline APA members, no division & 115 & 16 & \\
\hline \multicolumn{4}{|l|}{ APA Division } \\
\hline 1 Fellows & 54 & 7 & 26 \\
\hline Members & 35 & 5 & 4 \\
\hline 3 Fellows & 227 & 31 & 67 \\
\hline Members & 212 & 29 & 47 \\
\hline 5 Fellows & 39 & 5 & 7 \\
\hline Members & 42 & 6 & 3 \\
\hline 19 Fellows & 34 & 5 & 21 \\
\hline Members & 22 & 3 & 10 \\
\hline 21 Fellows & 14 & 2 & 34 \\
\hline Members & 22 & 3 & 6 \\
\hline Other Fellows & 98 & 13 & \\
\hline Members & 81 & 11 & \\
\hline
\end{tabular}

Note-Source: Newsletter of the Psychonomic Society, December 1960 (Verplanck, 1960e). Division 1 (General Psychology); Division 3 (Experimental Psychology); Division 5 (Evaluation and Measurement); Division 19 (Military Psychology); Division 21 (Engineering Psychologists). Based on 1960 APA Directory, and on PS membership as of September 1, $1960(N=736)$. (Multiple division affiliations preclude that the columns can be meaningfully added.) 
conduct of APA meetings was the primary stimulus for the formation of the new society. The hard-nosed experimentalists wanted data, data, and more data, with none of the APA frills.

The guidelines for who could present a paper were established in conjunction with the criteria for membership. The organizers were concerned that members should be able to present papers and that quality should be high. However, they were skeptical about their ability to judge a paper's quality from an abstract. They also wanted to keep administration simple and to avoid excessive work for a program committee. The decision was therefore made, patterned after the procedures of the American Physiological Society and the SEP, to place the quality control at the level of membership. Prospective members would have to show evidence of substantial research after the doctorate. Once a member, however, one could place one paper on the program each year. This could either be a presentation by the member or a paper sponsored by the member, but it could be only one paper. Members would be responsible for the quality of each paper that they gave or sponsored. This elegant solution served the society well. As noted by Morgan (1960b), "we think this combination of restrictive membership requirements and of open-door policy on attendance and giving of papers will best serve our purpose of having a scientific society holding scientific meetings" (p. 7). The job of the program committee, then, was simply to arrange papers into topics and to schedule time slots.

Initially, the presenter could set the amount of time desired, between 10 and 30 minutes, for the presentation of a paper. This practice continues today, though with choices of 10,15 , or 20 minutes for presentation plus 5 minutes for discussion.

The contrast with APA meetings was most sharply drawn with regard to other aspects of the program:

No special events, eg symposia, invited addresses, etc. will be scheduled. No commercial exhibits of any sort will be permitted. No formal relationship with, or provisions for, the press will be established. The Chairman of the Arrangements Committee will take such steps as are necessary to work with the University of Chicago's Public Relations Office. Reporters will not be barred; they will be referred to those giving papers for any special information they may request. (Verplanck, 1960c, p. 2)

This would be a meeting of experimentalists communicating with experimentalists, a stripped-down forum for scientific communication.

A poll revealed that $60 \%$ of the membership preferred that the annual meeting be held on a nearby university campus on dates overlapping those of the APA meeting. Resistance to this position was expressed at the first business meeting, and it was decided that a new mail ballot was in order (Verplanck, 1960c).

\section{Governance}

APA experiences also provided a strong negative model when the method of governance of the Psychonomic Society was established. The APA structure was regarded as bloated and complex; that of the Psychonomic Society would be simple and basic. The Society was not organized to lobby for legislation, to fight for licensure, or to support practice - -it was intended for scientific communication. "We decided we wanted the simplest kind of government that could get the job done without involving people in all sorts of committees or having business meetings that turn into debating societies" (Morgan, 1960b, p. 11).

The Governing Board, therefore, simply reserved for itself the power to do everything except elect board members and change the bylaws:

In other words, the members can select the memibers of the board, and throw them out if they don't like the way things are being run. But we are asking that once you select us, you entrust us to run the society in your interests in the most efficient possible manner. (Morgan, 1960b, p. 11)

The experience of the organizers with the autocratic structures of the Psychological Round Table and similar organizations is apparent.

Many societies choose leaders on the basis of scientific accomplishment or popularity alone, rather than for their ability to make sound administrative decisions. The Governing Board of the Psychonomic Society would be there to run the society - nothing else.

Not much business would be conducted at the business meeting; business would be the business of the Governing Board. Most significantly, there would be no popularly elected President. Rather, the Governing Board would elect a Chairman. The Board could better decide who would best administer the society for a year than could the membership at large. Further, term limits were introduced; a chairman could not succeed him- or herself, nor could a Secretary-Treasurer become permanent.

There would be no Presidential Address; indeed, there would be no President. Rather, the Chairman would make some "remarks" at the beginning of the business meeting. These could entail serious scientific discourse, a humorous address, as per the Psychological Round Table, or "some may cough a couple of times, tell you they have nothing to say, and proceed to the business meeting" (Morgan, 1960b, p. 1). Morgan's remarks as the first chairman, of course, were about the Society itself.

In order to give the new structure a chance to work, the autocratic Governing Board prohibited amendments to the bylaws for the first 2 years. However, they made provisions for the recall of officers after that (see Article IX in Appendix A).

\section{Finances}

The expenses involved in organizing the new society were met by begging and borrowing, though apparently no stealing. The resources of the Departments of Psychology at the Universities of Wisconsin and Maryland, where Morgan and Verplanck were located, were especially important.

At the Organizing Committee meeting, the Chicago Seven agreed that each committee member would advance 
the Society a loan of $\$ 10$ to get a treasury started. After the Society was incorporated on April 1, 1960, it could charge dues. The amount would be set at the annual business meeting; the organizers recognized that autocracy had its limits. The initial assessment was $\$ 2$ per year. Procedures for dropping members for nonpayment of dues were established. As noted above, by July 23, 1960, just 469 of the 720 charter members had paid dues.

As of the time of the first business meeting, the assets consisted of $\$ 1,012$ received in dues, $\$ 65$ in loans from the Governing Board, and $\$ 440$ in dues owed. The only expenditures were for stationery, printing, postage, and secretarial help in mailing the invitations, call for papers, and program.

The Governing Board grappled with the issue of a registration fee for meetings. At the first scientific meeting it was necessary to charge \$1, generating some \$261. The decision was made to apply any funds from dues that remained after office expenses to support the annual meeting. Any expenses above and beyond those supported in this way would come from a modest registration fee.

\section{Should There Be Journals?}

One of the two goals of the new society, as stated in the invitations to charter membership, was, if appropriate, to arrange for publications. The issue of journal publication was controversial from the beginning. This was one of the issues hammered at by the Chicago Seven. It was Morgan, then the Chairman of the APA Board of Publications, who argued most vociferously in favor of adding journals; Underwood was the most opposed (Verplanck, personal communication, October 27, 1994). The committee members were able to agree upon a noncommittal, compromise statement, "the New Society should be able to take advantage of such opportunities to edit or publish a journal as may arise in the near future" (Verplanck, 1959d, p. 3). Individual committee members agreed to take responsibility for exploring various publication possibilities.

In the summer of 1959, Verplanck contacted Parker Lichtenstein of Denison University about the possibility that the Psychological Record might become the official journal of the new society. Graham met with Carl Murchison in Worcester, Massachusetts, on June 23, 1960 to discuss the possibility of a journal of the Psychonomic Society within the Murchison journal stable. Murchison proposed that he might publish a supplementary volume of the Journal of General Psychology that would be specially labeled (Graham, 1960). Morgan sought advice from Karl Dallenbach, of the University of Texas, concerning possible arrangements with the American Journal of Psychology (Verplanck, 1960d). None of these efforts came to fruition. Publication of journals by the Psychonomic Society would evolve later in its history, initiated by a gift to the Psychonomic Society from Clifford Morgan.

\section{PERSPECTIVE}

Because of the breadth and diversity of psychology as a discipline, it is difficult for any one organization to meet the needs of all psychologists. Thus, throughout most of the history of the APA, various groups of psychologists, including practitioners, psychometricians, experimentalists, and others, have felt that the APA was not meeting their needs. They have frequently made efforts at forming alternative organizational structures (1) within the APA, (2) by forming groups in opposition to the APA, or (3) by forming organizations complementary to the APA.

The Psychonomic Society was founded as the result of the efforts of one group of experimentalists concerned with a variety of problems that they perceived within the APA, but especially with the nature of its annual conventions. What united these psychologists, working in different universities and different areas of psychology, was a focus on a no-nonsense scientific approach. The founders had little interest in the multiple contrasting faces and complexities of psychology. They supported a hard-nosed, no-frills discipline.

The pattern of events involved in the founding of the Psychonomic Society mimics earlier efforts in various significant respects. Though intended to complement the APA, the organization that emerged was the antithesis of the APA in many respects, being oriented toward simplicity and economy of function in serving limited purposes, whereas the APA pattern of complex bureaucratic structure evolved to meet the interests of as many diverse groups as possible. It was a reflection of its organizers, however - a very basic and focused organization designed to facilitate communication among scientists, to do it well, and to do little else.

The major features of the structure hammered out by the Chicago Seven and in the correspondence surrounding their 1959 meeting have survived in many significant respects. In an age of proliferating bureaucracies, it is perhaps remarkable that the economy, simplicity, and elegance of function of the Psychonomic Society have been preserved for so long. The Psychonomic Society was designed to do a few things and to do them well. In that effort it has proved quite successful.

\section{REFERENCES}

Anderson, J. E., Boring, E. G., Dallenbach, K. M., Dodge, R., Fernberger, S. W., Robinson, E. S., ANd Shepard, J. F. (1923, September 12). [Letter sent to Directors of Psychological Laboratories]. John F. Shepard Papers, Bentley Historical Library, University of Michigan.

Baldwin, J. M. (1901). Dictionary of philosophy and psychology (Vol. 2). New York: Macmillan.

Baldwin, J. M. (1902). Development and evolution. New York: Macmillan.

Benjamin, L. T., JR. (1977). The Psychological Round Table: Revolution of 1936. American Psychologist, 32, 542-549.

BoARd of SCIENTIFIC AfFAIRS [APA]. (1959). Technical communication in psychology: A statement of the problem. American Psychologist, 14, 267-271

Boring, E. G. (1938). The Society of Experimental Psychologists. American Journal of Psychology, 51, 410-423.

Boring, E. G. (1967). Titchener's experimentalists. Journal of the History of the Behavioral Sciences, 3, 315-325.

Brogden, W. J., Estes, W. K., Geldard, F. A., Graham, C. H., Humphreys, L. G., Morgan, C. T., Neff, W. D., Spence, K. W., 
STEVENS, S. S., \& UNDERwOOD, B. J. (1960). [Announcement of the formation of the Psychonomic Society]. American Psychologist, 15 , 281-282.

Dennis, W., \& Boring, E. G. (1952). The founding of the APA. American Psychologist, 7, 95-97.

DrEver, J. (1952). A dictionary of psychology. Harmondsworth, England: Penguin.

ENGLISH, H. B., \& ENGLISH, A. C. (1958). A comprehensive dictionary of psychological and psychoanalytic terms: A guide to usage. New York: David McKay.

EsTes, W. K. (1994, December 1). [Letter to H. L. Roediger III].

Evans, R. B., Sexton, V. S., \& CadWallader, T. C. (Eds.) (1992). 100 years: The American Psychological Association. A historical perspective. Washington, DC: American Psychological Association.

Fernibrger, S. W. (1932). The American Psychological Association: A historical summary, 1892-1930. Psychological Bulletin, 29, 1-89.

Garner, W. R. (1976). Clifford Thomas Morgan: Psychonomic Society's first chairman. Bulletin of the Psychonomic Society, 8, 409415.

Goodwin, C. J. (1985). On the origins of Titchener's experimentalists Journal of the History of the Behavioral Sciences, 21, 383-389.

Goodwin, C. J. (1992). APA round tables for "experimentalizers": Imitating Titchener's "Experimentalists"? Unpublished manuscript, Wheeling Jesuit College, Wheeling, WV.

Graham, C. H. (1960, June 24). Memorandum to the Chairman and members of the executive committee, Psychonomics [sic] Society; the secretary of the society. (Psychonomic Society Archives, Box 488.1, Folder 9). Akron, OH: University of Akron, Archives of the History of American Psychology.

Hilgard, E. R. (1987). Psychology in America: A historical survey. San Diego: Harcourt Brace Jovanovich.

HumphreYs, L. G. (1994, January 15). [Personal communication to H. L. Roediger III].

KenNEDY, J. L. (1960). Fifty-sixth annual meeting of the Society of Experimental Psychologists. American Journal of Psychalogy, 73, 320-321.

Morgan, C. T. (1959a, July 10). [Letter to William S. Verplanck]. (Psychonomic Society Archives, Box 510, Folder 10). Akron, OH: University of Akron, Archives of the History of American Psychology

Morgan, C. T. (1959b, August 13). [Letter to William S. Verplanck] (Psychonomic Society Archives, Box 510, Folder 10). Akron, $\mathrm{OH}$ University of Akron, Archives of the History of American Psychology.

MoRGAN, C. T. (1959c, August 13). Some thoughts on the need for a Society of Research Psychologists (Psychonomic Society Archives, Box 510, Folder 10). Akron, OH: University of Akron, Archives of the History of American Psychology.

MORGAN, C. T. (1960a, undated). [Letter to prospective charter members of the Psychonomic Society]. (Psychonomic Society Archives, Box 511, Folder 10). Akron, OH: University of Akron, Archives of the History of American Psychology.

Morgan, C. T. (1960b, September 2). [Untitled opening address to the business meeting of the Psychonomic Society, Chicago]. Unpublished manuscript, Psychonomic Society Publications, Austin, TX.

Mote, F. A. (1959, October 11). [Letter to William S. Verplanck] (Psychonomic Society Archives, Box 510, Folder 10). Akron, OH: University of Akron, Archives of the History of American Psychology

NAYLOR, J. G. (1994, November 3). [Personal communication to D. A. Dewsbury]
NEFF, W. D. (1960, January 13). [Letter to William S. Verplanck]. (Psychonomic Society Archives). Akron, $\mathrm{OH}$ : University of Akron, Archives of the History of American Psychology.

NELSON, W. A. (Ed.) (1956). Webster's new international dictionary of the English language (2nd ed.). Springfield, MA: G. \& C. Merriam.

RoE, A., Gustad, J. W., Moore, B. V., Ross, S., \& Skodak, M. (1959). Graduate education in psychology. Washington, DC: American Psychological Association.

SPENCE, K. W. (1959, July 10). [Letter to E. James Archer et al]. (Psychonomic Society Archives, Box 510, Folder 10). Akron, OH: University of Akron, Archives of the History of American Psychology.

3 ARRESTED HERE ON DIPLOMA MILL CHARGES. (1960, September 22). Los Angeles Times, p. 30

VERPLANCK, W. S. (1959a, August l). [In behalf of 10 psychologists: Letter to Frank A. Beach] (Psychonomic Society Archives, Box 510, Folder 10). Akron, OH: University of Akron, Archives of the History of American Psychology.

VERPLANCK, W. S. (1959b, July 24). [Letter to Clifford T. Morgan]. (Psychonomic Society Archives, Box 510, Folder 10). Akron, OH: University of Akron, Archives of the History of American Psychology.

VerplanCK, W. S. (1959c, August 17). [Letter to Clifford T. Morgan]. (Psychonomic Society Archives, Box 510, Folder 10). Akron, OH: University of Akron, Archives of the History of American Psychology.

VERPLANCK, W. S. (1959d). Minutes of the first meeting of the Organizing Committee/Governing Board of the New Society [December 29-30] (Psychonomic Society Archives, Box 488.1, Folder 22). Akron, $\mathrm{OH}$ : University of Akron, Archives of the History of American Psychology.

VERPLANCK, W. S. (1960a, January 5). [Letter to C. H. Graham]. The Psychonomic Society Newsletter 1960 (Psychonomic Society Archives, Box 510, Folder 2). Akron, OH: University of Akron, Archives of the History of American Psychology.

VERPLANCK, W. S. (1960b, March 18). [Letter to members of the Governing Board] (Psychonomic Society Archives, Box 510, Folder 2). Akron, $\mathrm{OH}$ : University of Akron, Archives of the History of American Psychology.

VERPLANCK, W. S. (1960c). Minutes of the first (informal) meeting of the Governing Board Madison, Wisc., March 31 and April 1, 1960 (Psychonomic Society Archives, Box 488.1, Folder 22). Akron, $\mathrm{OH}$ : University of Akron, Archives of the History of American Psychology.

VERPLANCK, W. S. (1960d). Minutes of the second meeting of the Governing Board Chicago, Ill., 1 September, 1960 [erroneously listed as 1961 in original] (Psychonomic Society Archives, Box 488.1, Folder 2). Akron, OH: University of Akron, Archives of the History of American Psychology.

Verplanck, W. S. (1960e, December 31). The Psychonomic Society Newsletter 1960 (Psychonomic Society Archives). Akron, OH: University of Akron, Archives of the History of American Psychology.

VerplancK, W. S. (1991, November 2). Psychonomic Society: Foreplay to maturity. Unpublished manuscript.

WARREN, H. C. (1934). Dictionary of psychology. Boston: Houghton Mifflin.

WATSON, R. I. (1953). A brief history of clinical psychology. Psychological Bulletm, 50, 321-346.

WITMER, L. (1925). Psychological diagnosis and the psychonomic orientation of analytic science. Psychological Clinic, 16, 1-18. 


\section{APPENDIX A \\ Original Bylaws of the Psychonomic Society}

\section{BY-LAWS OF THE PSYCHONOMIC SOCIETY}

\section{ARTICLE I: NAME AND OBJECT}

1. The name of the society is the Psychonomic Society.

2. The object of the society is to promote the communication of scientific research in psychology and allied sciences.

\section{ARTICLE II: MEMBERSHIP}

1. The society shall have one class of membership.

2. Members shall be persons qualified to conduct and to supervise scientific research in psychology or allied sciences. To be eligible for membership, a person must hold the $\mathrm{Ph}$.D. degree or equivalent, and must have published significant research other than the doctoral dissertation.

3. Eligible persons shall be considered for membership by the Governing Board. Any member may recommend individuals to the Board for its consideration. The Board shall elect those individuals it considers eligible for membership and report their names at the Annual Business Meeting.

4. During the calendar years 1960 and 1961, all persons invited to become Charter Members by the Governing Board and who accept election before December 31, 1961, shall be members.

\section{ARTICLE III: GOVERNING BOARD}

1. The Governing Board shall exercise general supervision over the affairs of the society, subject to the provisions of Articles IX and $\mathrm{X}$.

2. The Governing Board shall consist of twelve members, elected for staggered terms of six years each, and, ex-officio, the Secretary-Treasurer of the Society, if he is not already a member. (The ten members of the Organizing Committee of the society shall constitute the Governing Board until the Charter Members have elected two more members for six year terms. The terms of Charter Members of the Governing Board shall be staggered so that the two members most senior in age shall serve one year, the two next most senior in age two years, and so on.) Except for Charter Members of the Board serving three years or less, members of the Governing Board may not succeed themselves.

3. The Governing Board shall elect its own Chairman by written, secret ballot. The term of the Chairman shall be one year, and he may not succeed himself.

4. The Governing Board shall from time to time appoint such committees as it deems necessary to conduct the affairs of the association.

5. The Chairman of the Governing Board shall preside at meetings of the Board and at the Annual Business Meeting.

\section{ARTICLE IV: OFFICERS}

1. The officers of the society shall be the Chairman of the Governing Board and the Secretary-Treasurer.

2. The Secretary-Treasurer shall be elected by the Governing Board to serve a term of three years. He may be re-elected once, but may not serve more than six consecutive years.

3. The Secretary-Treasurer shall keep a list of the membership of the society, collect dues, and make disbursements of funds as directed by the Governing Board.

\section{ARTICLE V: ELECTIONS}

1. Once each year, the Secretary-Treasurer shall canvass the membership by mail for nomination of persons to serve on the Governing Board. Each member may nominate up to four persons.

2. The names of the six persons receiving the greatest number of nominations, and who signify their willingness to serve, shall be placed on an election ballot, which shall be mailed to all members. Each member may vote for two persons named on the ballot. 
3. Sixty days after the mailing of the election ballot, the election shall be closed, and the ballots counted. The two persons receiving the greatest number of votes shall be elected members of the Governing Board.

4. In the case of resignation, recall, or death of a member of the Governing Board, the vacancy shall be filled in conformity with Sections 1, 2, and 3 above, that is, six nominations will be requested, nine names shall be placed on the election ballot, and each member shall vote for three persons. The third ranking candidate shall complete the unfilled term of office, but may then succeed himself.

\section{ARTICLE VI: MEETINGS}

1. The society shall hold an Annual Scientific Meeting at a time and place selected by the Governing Board.

2. Any member may present a scientific paper at the Annual Meeting. A non-member may present a paper when sponsored by a member.

3. An Annual Business Meeting shall be held in conjunction with the Scientific Meeting. Only members of the society may attend the Annual Business Meeting.

4. All motions at the Annual Business Meeting require only a simple majority for passage.

\section{ARTICLE VII: PUBLICATIONS}

1. The society shall publish such programs, abstracts of scientific papers, and list of membership, as the Governing Board shall authorize. With approval of the membership, the Governing Board may undertake the editing, or publishing, or both, of scientific journals.

\section{ARTICLE VIII: DUES}

1. The annual dues of membership shall be determined by the membership at the Annual Business Meeting upon recommendation of the Governing Board, except that the dues during the calendar year 1960 and 1961 shall be no less than $\$ 2.00$.

2. A member failing to pay dues for two consecutive years shall be considered to have resigned, but may be reinstated any time in the three years following upon payment of all back dues.

3. A member failing to pay dues for five years may be reinstated only by satisfying the requirements for the election of new members prescribed in Article II.

\section{ARTICLE IX: RECALL}

1. Upon petition of $10 \%$ of the membership, an election by mail ballot will be held on proposals with respect to the recall of members of the Governing Board, or of the Secretary-Treasurer. Such recall will be effective upon a majority mail vote of all members of the society, but the recalled member shall continue to serve until replaced in accordance with the election procedure prescribed in Article V.

\section{ARTICLE X: AMENDMENTS}

1. These by-laws may not be amended until Charter Membership is complete, that is, until December 31, 1961. Amendments may be proposed by the Governing Board or by passage of a motion from the floor at the Annual Business Meeting, for action by mail of the entire membership. A two-thirds majority of those voting on the mail ballot shall be required for the adoption of an amendment. Any proposed amendment shall be presented to the membership with the recommendation of the Governing Board.

2. At the Annual Business Meeting in 1962, the Governing Board shall present amendments designed to eliminate references to Charter Members and other provisions relating solely to the period 1960 and 1961 .

These by-laws were formally adopted in Chicago, Illinois, on 30 December, 1959 


\section{APPENDIX B \\ Invitation to Charter Membership in the Psychonomic Society}

THE PSYCHONOMIC SOCIETY

Organizing Committee

\author{
W. J. Brogden \\ W. K. Estes \\ F. A. Geldard \\ C. H. Graham
}

\author{
L. G. Humphreys \\ C. T. Morgan, Chairman \\ W. D. Neff \\ K. W. Spence
}

\author{
S. S. Stevens \\ B. J. Underwood \\ W. S. Verplanck, \\ Secretary-Treasurer
}

Dear Fellow Psychologist:

The Psychonomic Society has been organized with two purposes: (1) to arrange for, and to conduct, appropriate and annual meetings for the dissemination of results of recent research in scientific psychology; and (2) if it should prove desirable, to produce media in which papers reporting such research can be published.

Through these aims it is hoped to preserve and to foster high scientific standards for psychological research and the traditional academic values associated with a scientific discipline.

The membership and activities of the society will be guided not so much by specific content area in which such research is done as by the serious nature of the research and by the methodology followed.

Two enclosures, one an announcement to be published in the American Psychologist and the other the society's By-Laws, summarize the considerations entering into the formation of the society.

It is our expectation that annual dues can be kept to a minimum by maintaining a simple administration, just as the cost of conducting and attending the meetings will be kept low, since, with the anticipated membership, we should be able to meet in academic facilities.

With this letter, the Organizing Committee invites you to join the society as a Charter Member. Many persons meeting the criteria adopted by the committee for Charter Membership, that is, those who have proven competence in scientific psychological research, and who hold the Ph.D. degree, are being invited at this time.

You may accept this invitation by filling out and returning the enclosed postcard. Upon incorporation of the society, which is in progress, payment of initial dues of $\$ 2.00$ will be requested of its Charter Members.

We hope that you will join us and also that you will wish to present a paper at the first meeting, which will be held on the campus of the University of Chicago, September 1,2, and 3, 1960. Any member will be entitled to present, or alternatively to sponsor the presentation, of a paper. The call for papers will be made in about two months.

Sincerely,

CLIFFORD T. MORGAN

Chairman 


\section{APPENDIX C \\ Earty Uses of the Term Psychonomic and its Congeners}

In the first newsletter, Verplanck (1960e) reported that "Members Joe Zubin and Gregory Razran each were happy to report recently encountering the word 'psychonomic (psychonomisch)' in the literature.

In reality, the term had appeared in other literature in psychology. Apparently, none of the organizers were familiar with these uses. There is considerable diversity in the earlier definitions. One of the founders of the APA, James Mark Baldwin (1861-1934), wrote:

The flow of the psychic, we find, however, so soon as we go over to the objective or "psychological" point of view, is conditioned upon physiological processes and functions - those of the brain and other organs. These latter condition-limit, further, direct, inhibit, in any way modify-the flow of the psychic changes. Such conditions are "psychonomic." This term may be used to denote the entire sphere of phenomena which are in connection with the psychological, but which, nevertheless, are not intrinsic to the series of psychic changes as such. Psychology, when considered as the science of mind, in its evolution as well as in its development, - of mind, that is, looked at from the objective point or view,--takes cognizance of the "psychonomic"; but when considered as a subjective science, as interpreting its own data, it does not; but, on the contrary, it confines itself to the psychic. (Baldwin, 1902, p. 8; emphasis in original)

Despite Baldwin's dense prose, we think that the organizers would have resonated to his use of psychonomic, especially his emphasis on objectivity.

The term was used by Lightner Witmer (1925) as follows: "Psychonomic is a word which denotes what is in conformity to a fundamental of universal law or thought" (p. 8). Witmer regarded psychonomics as broader than, but inclusive of, psychoanalysis: "The psychonomic analysis of human behavior is concerned with what is considered normal and orthogenic, and only by way of exception with what is considered non-normal and pathogenic" (p. 8, emphases in original).

Psychonomic and its derivatives also are defined in the leading dictionaries of psychology of the century, but these appear not to have been consulted by the society's founders. In his influential Dictionary of Philosophy and Psychology, Baldwin (1901) defined both psychonomic forces and psychonomics, noting for the latter that "this branch of inquiry treats, from the objective or sociological point of view, the data with which SOCIAL PSYCHOLOGY (q.v.) deals from the subjective or psychic point of view" (p. 391). This links well with the quotation above.

Warren (1934) also defined both psychonomic forces and psychonomics, providing a more developmental emphasis:

psychonomics $=1$. that branch of psychology which investigates the relation of the individual mind, and its development, to the environment, both physical and social; 2. (hist.) the science of mental laws (p. 218).

Psychonomic forces are "the various active conditions which play a part in mental development (p. 218).

Drever (1952) defined psychonomic as a "term employed of conditions and influences affecting mental development; from a social point of view, of mental forces determining or playing a part in social organization" and psychonomics in a related manner" (p. 228).

For English and English (1958), psychonomic relates to psychic law; they add that "the term is general and may be given special meaning by the writer" (p. 427). A definition related to development is provided as secondary.

Perhaps the most bizarre use surfaced in September, 1960, the month of the first scientific meeting of the Psychonomic Society. According to the Los Angeles Times, "Two men and a woman accused of operating a 'diploma mill' issuing fake doctorate degrees in the field of psychonomy (study of the mind) were arrested" (" 3 arrested here on diploma mill charges," 1960). One of the men arrested was identified as the president of the Psychonomic Research Center, allegedly a front operation granting bogus advanced degrees. One wonders whether the Psychonomic Society provided any inspiration for this endeavor.

It is not clear how and why the term psychonomic has taken on these varieties of meaning during this period. The questions are worthy of investigation, though beyond the scope of this study at this time. Clearly, the founders of the Psychonomic Society used psychonomic in a manner not suggestive of the developmental and social connotations suggested in the dictionaries. 


\section{APPENDIX D \\ An Eyewitness Account of the December 29-30, 1959 \\ Meeting of the Organizing Committee, Morrison Hotel, Chicago, as Written by William S. Verplanck and Lloyd G. Humphreys, November, 1994}

The Psychonomic Society was founded by the seven members of the Organizing Committee meeting at the Morrison. The following is the first-hand account given by the only two surviving participants able to contribute. Described in the unedited words of these participants, the very informal, if not disorderly meeting proceeded as follows

The seven who met in that smoke-filled, wet-barred room in Chicago shared in their goal of a new society, as well as in their unquestioned status as psychologists of demonstrated leadership, scientific excellence, experience in the governance of scientific societies, and mutual respect. All could recollect the good old days, when APA could meet at Penn State, and EPA at Bryn Mawr. Morgan, on the basis of his work in the preceding month or two, provided as agenda a draft set of bylaws. Chairman by default, he restricted himself to moving the agenda forward; he entered into discussions and arguments as fully as the others. A "take-charge" kind of person, he did not take charge of this group. Informality ruled; Robert's Rules of Order were replaced by common courtesy, which was occasionally breached. The draft bylaws could have been adopted as written in half an hour at most; the OC Meeting, however, took two days to write those finally accepted. There was plenty to talk about: How big would or should the meetings be? Why should we worry about that when we have no members yet? What about a name? Where should we try to meet? There were jokes(?): Should GB members be expected to present a paper at every meeting? (NO!) Isn't it silly to worry about how to restrict the number of papers at a meeting when we don't have any members but us?

Issues of governance were settled easily: it was the intent to make it as different from APA as could be. The $\mathrm{OC}$ was in agreement that the governance structure adopted conformed to that of a proper scientific society. Action on one issue that provoked extended discussion - publication of journals - was deferred to the Governing Boards of the future. Nor could a name be settled on. Early on, three names were considered: Psychobiology Society, Biopsychology Society, and Psychonomic Society. The last started low in the OC's regard, but gained favor as the meeting progressed. Reminded of the absent Graham's strong preference for something like "Federation of Experimental Psychologists," the Secretary was instructed to take a mail poll of all ten OC members as soon as possible.

The lengthiest and most intensely discussed question was that of the core, the nature of the society. Some took an elitist stand, viewing the society as a sort of SEP or PRT, with no limits on size, no invitations, no secrecy, but with a high standard for membership, with only members permitted to present papers. The "populists" proposed that any psychologist, whether PhD or graduate student, could join and submit a paper for acceptance. The society's purpose, they argued, was to encourage psychologists (including graduate students) to perform and to report on research early and often. Through all this, the secretary tried in vain to keep orderly notes, but could ensure only that he had correctly written down successive decisions as they emerged. The Bylaws, as hammered out, were polished up by Morgan and Verplanck before a final meeting of the OC adopted their resolutions of long, carefully examined and thoroughly argued issues. The "new society," still nameless, was founded. 